\title{
Two kinds of rare light chain cast nephropathy caused by multiple myeloma: case reports and literature review
}

\author{
Li-Jun Sun, Hong-Rui Dong, Xiao-Yi Xu, Guo-Qin Wang, Hong Cheng and Yi-Pu Chen ${ }^{*}$
}

\begin{abstract}
Background: Light chain cast nephropathy (LCCN) is the most common renal disease caused by multiple myeloma (MM). In addition to ordinary light chain protein casts, there are a few rare casts with unique shapes, including light chain amyloid casts (LCAC) and light chain crystal casts (LCCC).

Case presentations: Here, we report two patients. Patient 1 is a 72-year-old man who was clinically diagnosed with MM and acute kidney injury (AKI). Pathological examination of a renal biopsy revealed that there were many amyloid casts in the distal tubules that had a lightly-stained central area and a deeply-stained burr-like edge. The marginal zone of the cast was positive for Congo red staining and contained numerous amyloid fibers, as observed by electron microscopy. No systemic amyloidosis was found. The patient received 4 courses of bortezomib-based chemotherapy, and then, his MM achieved partial remission. Patient 2 is a 57-year-old man who was also clinically diagnosed with MM and AKI. Pathological examination of a renal biopsy showed that there were many crystalline casts in the distal tubules that were fully or partially composed of crystals with different shapes, including rhomboid, needle, triangle, rectangle and other geometric shapes. Congo red staining was negative. Crystals were also detected in the urine of this patient. After 9 courses of treatment with a bortezomib-based regimen, his MM obtained complete remission and his renal function returned to normal.

Conclusions: LCAC and LCCC nephropathy caused by MM are two rare types of LCCN, and both have their own unique morphological manifestations. LCAC nephropathy may not be accompanied by systemic amyloidosis. The diagnosis of these two unique LCCNs must rely on renal biopsy pathology, and the discovery of urine crystals is of great significance for indicating LCCC nephropathy.
\end{abstract}

Keywords: Multiple myeloma, Light chain, Cast nephropathy, Amyloid casts, Crystalline casts, Acute kidney injury, Renal biopsy, Urinalysis

\section{Background}

Multiple myeloma (MM) is a malignant neoplasm caused by clonal hyperplasia of plasma cells in the bone marrow $[1,2]$. Renal impairment is common and is frequently the initial presentation of MM. It is reported that 20 to $50 \%$ of patients had kidney involvement at the

\footnotetext{
*Correspondence: chen_yipu@163.com

Division of Nephrology, Beijing Anzhen Hospital, Capital Medical University, No.2 Anzhen Street, Chaoyang District, Beijing 100029, People's Republic of China
}

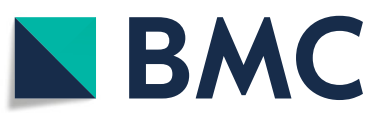

time of MM diagnosis [1-3]. MM can cause a variety of types of renal damage, among which, light chain cast nephropathy (LCCN) is the most common and usually leads to acute kidney injury (AKI). Moreover, MM can also cause renal amyloidosis, monoclonal immunoglobulin deposition disease, type I cryoglobulinemic glomerulonephritis, and rarely light chain proximal tubulopathy (LCPT) [1-3].

Light chain casts are formed through the following processes: a large number of monoclonal free light chain

(c) The Author(s). 2021 Open Access This article is licensed under a Creative Commons Attribution 4.0 International License, which permits use, sharing, adaptation, distribution and reproduction in any medium or format, as long as you give appropriate credit to the original author(s) and the source, provide a link to the Creative Commons licence, and indicate if changes were made. The images or other third party material in this article are included in the article's Creative Commons licence, unless indicated otherwise in a credit line to the material. If material is not included in the article's Creative Commons licence and your intended use is not permitted by statutory regulation or exceeds the permitted use, you will need to obtain permission directly from the copyright holder. To view a copy of this licence, visit http://creativecommons.org/licenses/by/4.0/ The Creative Commons Public Domain Dedication waiver (http://creativecommons.org/publicdomain/zero/1.0/) applies to the data made available in this article, unless otherwise stated in a credit line to the data. 
proteins are synthesized by clonal hyperplasic plasma cells in the bone marrow and secreted into circulation. These proteins then pass through the glomerular filtration membrane to reach the renal tubules and are endocytosed by proximal tubular epithelial cells. When the endocytosis of the epithelial cells reaches saturation, the excess light chain proteins remain in the tubular fluid and flow through Henry's loop, where they combine with uromodulin and then form casts in the distal tubular lumen [2-4]. The light chain casts usually show a "fractured" appearance and are surrounded by mononuclear cells and multinuclear giant cells. The casts appear red with hematoxylin-eosin (HE) staining, polychromatic with Masson trichrome staining, and light or negative with periodic acid-Schiff (PAS) staining and periodic acid silver methenamine (PASM) staining. Immunofluorescence (IF) or immunohistochemical examination reveals that the light chain protein in casts is monoclonal light chain $\lambda$ or $\mathrm{k}[3,5,6]$. However, in rare cases of $\mathrm{MM}$, some casts with unusual shapes can also be seen, including light chain amyloid casts (LCAC) and light chain crystal casts (LCCC), can also be seen. In recent years, we have diagnosed one patient with LCAC nephropathy and one patient with LCCC nephropathy. Here, we provide a case report and literature review on these patients.

\section{Case presentations}

\section{Case 1}

A 72-year-old man was admitted to our hospital due to weakness and elevated serum creatinine level. Eight months prior to admission, (+) urinary protein and $115.1 \mu \mathrm{mol} / \mathrm{L}$ serum creatinine (reference value 57$111 \mu \mathrm{mol} / \mathrm{L}$ ) were observed in this patient. His serum creatinine level had increased to $282.8 \mu \mathrm{mol} / \mathrm{L} 3$ months prior to admission and to $461.4 \mu \mathrm{mol} / \mathrm{L} 6$ days prior to admission. The patient had a 15-year history of hypertension. On admission, the patient's blood pressure was 132/86 mmHg. Physical examination found no remarkable abnormality except a slightly pale face. The laboratory tests results were as follows: hemoglobin level was $97 \mathrm{~g} / \mathrm{L}$; urine protein (dipstick test) was (+); 24-h proteinuria was $4.19 \mathrm{~g}$; serum albumin level was $35.8 \mathrm{~g} / \mathrm{L}$; serum globulin level was $20.1 \mathrm{~g} / \mathrm{L}$; serum calcium level was $3.39 \mathrm{mmol} / \mathrm{L}$; serum creatinine level varied between 445.9 and $682.7 \mu \mathrm{mol} / \mathrm{L}$; urine osmotic pressure was $330 \mathrm{mOsm} /$ $\mathrm{kg} \cdot \mathrm{H}_{2} \mathrm{O}$ (reference value $600-1000 \mathrm{mOsm} / \mathrm{kg} \cdot \mathrm{H}_{2} \mathrm{O}$ ); urine $\alpha-1$ microglobulin level was $190 \mathrm{mg} / \mathrm{L}$; serum IgA, IgG and IgM levels were all decreased $(0.33 \mathrm{~g} / \mathrm{L}, 6.16 \mathrm{~g} / \mathrm{L}$ and $0.06 \mathrm{~g} / \mathrm{L}$, respectively); and serum complement $\mathrm{C} 3$ and $\mathrm{C} 4$ levels were normal. In addition, immunofixation electrophoresis revealed that there were monoclonal IgG $\mathrm{k}$ and $\mathrm{k}$ light chain in the patient's serum and urine, respectively (Supplementary file 1: Fig. S1). Serum free light chain measurement ( $\mathrm{N}$ Latex FLC kappa \& lambda assay) showed that the $\mathrm{K}$ light chain level was $9270.0 \mathrm{mg} / \mathrm{L}$ (reference value $6.7-22.4 \mathrm{mg} / \mathrm{L}$ ), the $\lambda$ light chain level was $58.2 \mathrm{mg} / \mathrm{L}(8.3-27 \mathrm{mg} / \mathrm{L})$ and the $\mathrm{k} / \lambda$ ratio was 159.3 (0.31-1.56). Bone marrow smear examination showed that the percentage of immature plasma cells was $27.5 \%$. X-ray examination showed multiple osteolytic lesions in the pelvis. Thus, IgG к-type MM was diagnosed.

A renal biopsy was performed. Light microscopy revealed that there were 15 glomeruli in the section, of which, 7 were of ischemic sclerosis showing 'wrinkling collapse' of the glomerular capillary tuft and the rest were not significantly abnormal. There were many casts in the lumen of distal tubules. Approximately 35\% of the casts were ordinary light chain protein casts with a "fractured" appearance surrounded by mononuclear cells and occasionally by multinucleated giant cells (Fig. 1 A). Approximately $65 \%$ of the casts showed a unique shape with a lightly-stained central area and a deeply-stained burr-like edge, which was black with PASM staining, blue with Masson trichrome staining and fuchsia with PAS staining (Fig. $1 \mathrm{~b}$ to d). The marginal zone of the casts was Congo red positive (Fig. 1e to g), while the glomeruli and renal arterioles were negative. There was multifocal interstitial fibrosis (accounting for 65\% of the interstitial area) with moderate mononuclear cell infiltration and renal tubule atrophy. The walls of the renal arterioles were moderately thickened with hyaline deposits. Immunofluorescence examination showed $\mathrm{k}$ light chain restriction in the unique casts ( $\kappa$ light chain was strongly positive, while $\lambda$ light chain negative) (Fig. $1 \mathrm{~h}$ and i). Electron microscopy revealed that numerous randomly arranged unbranched fibrils with a diameter of $8-12 \mathrm{~nm}$ existed in the marginal zone of the unique casts (Fig. 1j). Therefore, the pathological diagnosis was LCAC nephropathy, k-type, and benign hypertensive nephrosclerosis. In addition, bone marrow biopsy and periumbilical subcutaneous adipose pad biopsy were also performed. The pathological diagnosis of the bone marrow was plasmacytoma. Congo red staining was negative in the bone marrow, subcutaneous adipose tissue and arterioles.

The patient received 3 courses of bortezomib, dexamethasone and cyclophosphamide triple chemotherapy, and then 1 course of bortezomib, dexamethasone, cyclophosphamide and etoposide quadruple chemotherapy. After treatment, the monoclonal band of serum immunofixation electrophoresis disappeared and the ratio of serum free light chain $\mathrm{K} / \lambda$ decreased to 71.4 , but the renal function did not improve. Thereafter, the patient ceased chemotherapy, switched to traditional Chinese medicine, and underwent maintenance hemodialysis.

\section{Case 2}

A 57-year-old man was admitted to our hospital because of bone pain and raised serum creatinine. He has felt multiple bone pain for 1 month. Six days prior to 

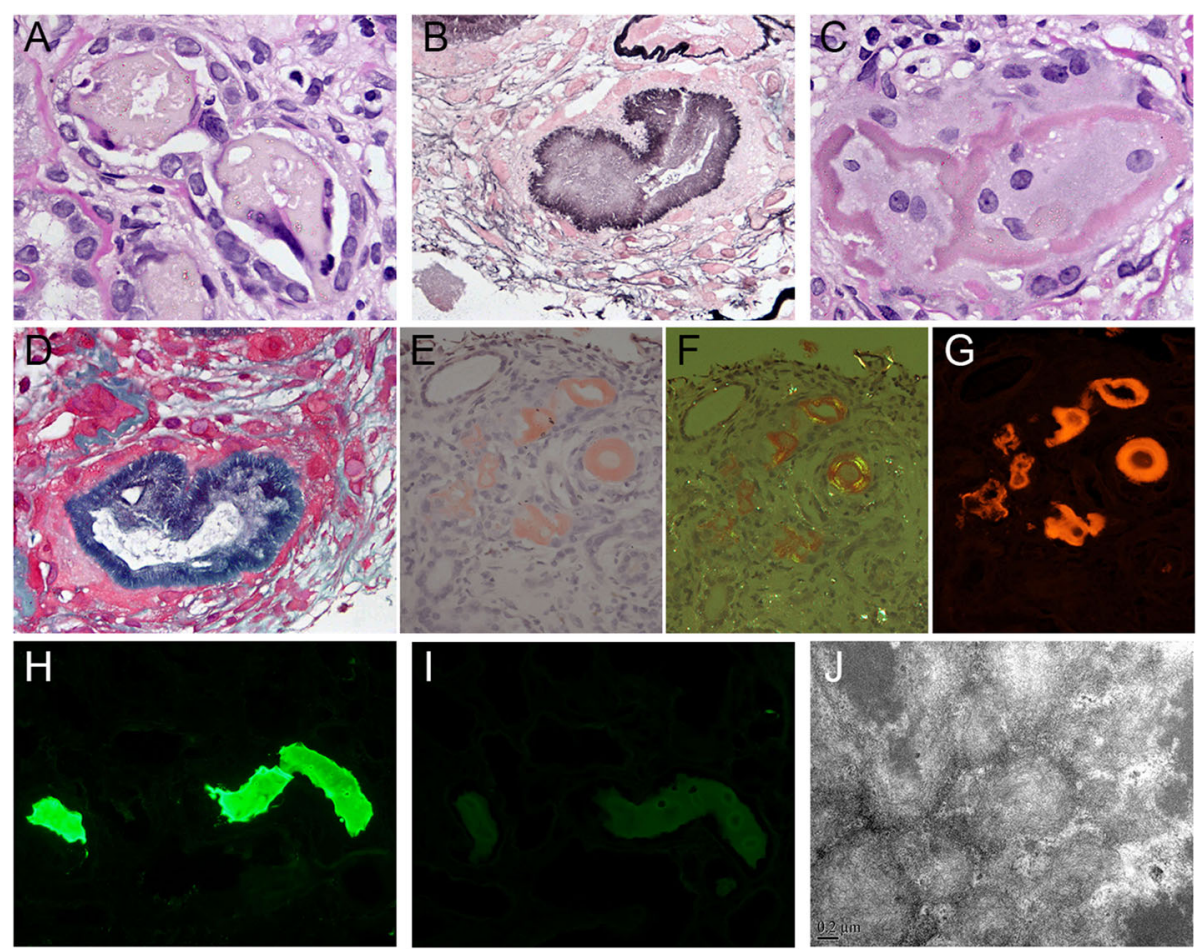

Fig. 1 Pathologic findings of kidney biopsy tissue in Case 1. An ordinary protein cast with a "fractured" appearence and peripheral cellular reaction, which was weakly stained in PAS staining (a) (original magnification $\times 1000$ ). A cast with an unique shape, that had a lightly stained central area and a deeply stained burr-like edge in PASM-Masson trichrome double staining (b), PAS staining (c) and Masson trichrome staining (d) (original magnification $\times 1000$ ). The above unique casts stained with Congo red under ordinary light microscope (e), polarized light microscope $(\mathbf{f})$ and fluorescence microscope $(\mathbf{g})$ (original magnification $\times 400)$. The unique casts with strong staining of $\mathrm{k}$ light chain $(\mathbf{h})$ and $\mathrm{no}$ staining of $\lambda$ light chain (i) (fluorescence micrographs $\times 400$ ). Numerous randomly arranged unbranched fibrils with a diameter of $8-12 \mathrm{~nm}$ in a unique cast (j) (electron micrograph $\times 50,000)$

admission, a small amount of proteinuria $(+)$ and slightly elevated serum creatinine levels, reaching $162.9 \mu \mathrm{mol} / \mathrm{L}$, were observed in this patient. His significant medical history was 26 years of mild hypertension. At admission, the patient's blood pressure was $131 / 82 \mathrm{mmHg}$ and physical examination showed no abnormalities. His hemoglobin level was $105 \mathrm{~g} / \mathrm{L}$. Urine protein (dipstick test) was trace $( \pm)$ and 24 -h proteinuria was $5.4 \mathrm{~g}$. Many clustered or scattered crystals of needle shape and other shapes were detected in his urinary sediment by light microscopy (Fig. 2). The serum albumin level was $39.8 \mathrm{~g} / \mathrm{L}$, and the globulin level was $31.0 \mathrm{~g} / \mathrm{L}$. The serum calcium level was $3.66 \mathrm{mmol} / \mathrm{L}$. The serum creatinine level was $223.5 \mu \mathrm{mol} / \mathrm{L}$. The urine osmotic pressure was $250 \mathrm{mOsm} /$
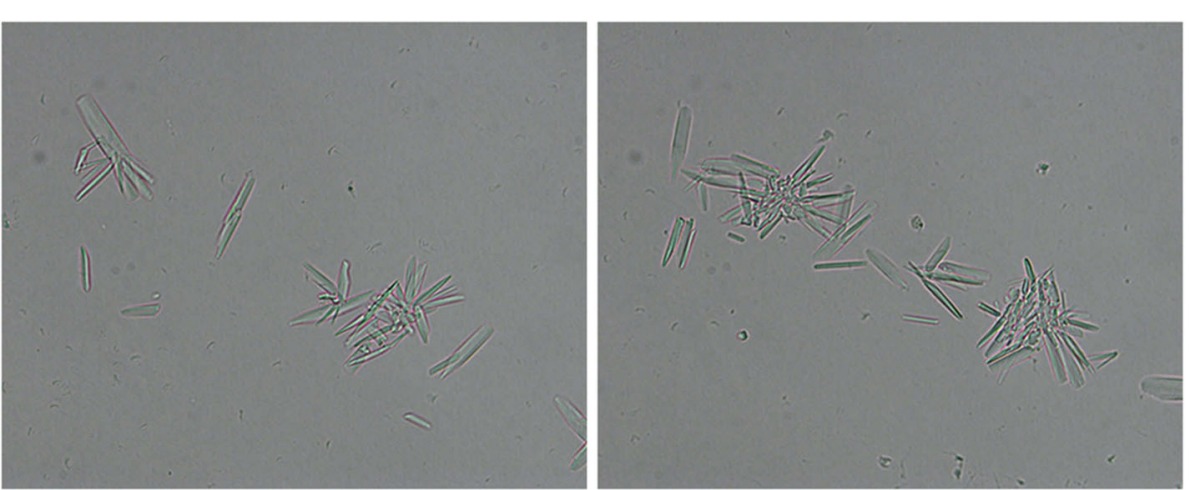

Fig. 2 Light microscopy of urinary sediment after centrifugation. Many clustered or scattered crystals of needle shape and other shapes in the urine (original magnification $\times 1000$ ) 
$\mathrm{kg} \cdot \mathrm{H}_{2} \mathrm{O}$, and the urine $\alpha-1$ microglobulin level was 33.1 $\mathrm{mg} / \mathrm{L}$. The serum IgA, IgG and IgM levels were all decreased $(0.37 \mathrm{~g} / \mathrm{L}$, IgG $6.66 \mathrm{~g} / \mathrm{L}$ and IgM $0.06 \mathrm{~g} / \mathrm{L}$, respectively). The serum complement $\mathrm{C} 3$ and $\mathrm{C} 4$ levels were normal. Monoclonal $\lambda$ light chain was detected in the serum and urine by immunofixation electrophoresis (Supplementary file 1: Fig. S2). The serum free light chain assay showed that the $\mathrm{\kappa}$ light chain level was $15.8 \mathrm{mg} / \mathrm{L}$, the $\lambda$ light chain level was $1310.0 \mathrm{mg} / \mathrm{L}$ and the $\mathrm{k} / \lambda$ ratio was 0.012 . Bone marrow smear examination revealed that the percentage of immature plasma cells was $36.5 \%$. Multiple osteolytic lesions in the skull, mandible and pelvis were observed in the X-ray films. Thus, the diagnosis of $\lambda$-type light chain MM was established.

A renal biopsy was carried out. Light microscopy revealed there were 1 glomeruli in the renal biopsy tissue sections and they were all basically normal. In the distal tubular lumen, there were many casts, of which, approximately $65 \%$ were ordinary light chain protein casts that usually had a "fractured" appearance and were surrounded by cellular reaction. The rest, $35 \%$, were unique crystalline casts, which were fully or partially composed of crystals with different shapes, including rhomboid, needle, triangle, rectangle and other geometric shapes. These casts were red with HE staining and Masson trichrome staining, but not colored with PAS staining and PASM staining. Cellular reactions surrounding some crystalline casts could also be seen (Fig. 3a to d). The renal interstitium showed focal fibrosis (less than $25 \%$ of the total interstitial area) with mild mononuclear cell infiltration and renal tubule atrophy. No crystal deposition was found in the renal arteriolar lumen. Congo red staining in the renal parenchyma was negative. Immunofluorescence examination showed that the $\lambda$ light chain staining of the crystalline casts was positive, while the $\kappa$ light chain was negative, suggesting $\lambda$ light chain restriction (Fig. 3e and f). Electron microscopy revealed many rhombic, rectangular, triangular or irregular crystals in the unique casts (Fig. $3 g$ and h). Hence, the pathological diagnosis was LCCC nephropathy $\lambda$-type. Bone marrow biopsy was also performed, and its pathological diagnosis was plasmacytoma. No crystal could be found in the bone marrow tissue.

After diagnosis was confirmed the patient received bortezomib, lenalidomide and dexamethasone triple chemotherapy for a total of 9 courses. His MM achieved complete remission. Serum and urine immunofixation electrophoresis, serum free light chain concentration and serum IgA, IgG, IgM levels had all returned to normal, and the serum creatinine level and estimated glomerular filtration rate also returned to normal.

\section{Discussion and conclusions}

$\mathrm{LCCN}$ is the most common MM-related renal disease. According to a Mayo Clinic report, LCCN accounts for
33\% of all cases of MM-related kidney diseases [1]. However, LCAC nephropathy and LCCC nephropathy are very rare variants. We used Medline and EMBASE database retrieval and manual retrieval to collect articles and case reports of LCAC and LCCC nephropathy written in English for literature review. Abstracts of conference proceedings that were not published in full were not included (Supplementary file 2).

In 1962, when Vassar et al. [7] and Azzopardi et al. [8] first reported LCACs when they observed these unique morphological casts in autopsies of patients with MM. From 1962 to 1980, LCACs were found in approximately 55 autopsy patients with $\mathrm{MM}$, and in about $2 / 3$ of these patients, amyloid casts were diagnosed only by methyl violet staining and/or thiocyanin $\mathrm{T}$ staining [7-12]. From 1980 to 2020, only 25 patients with LCACs caused by $\mathrm{MM}$ were identified (renal biopsy in 24 cases and autopsy in 1 case), and the diagnosis of amyloid casts in these patients was based on Congo red staining and/or electron microscopy $[6,13-21]$ (Table 1). In addition, in three other papers the authors mentioned that they also observed LCACs in some patients with renal damage caused by MM, but they did not provide a detailed description [22-24].

Unlike the ordinary light chain protein cast, LCAC has a unique shape. In most cases, it has a lightly stained central area and a deeplystained burr-like edge, which is black, blue and fuchsia with PASM, Masson trichrome and PAS staining, respectively. Positive Congo red staining and electron microscopy can confirm its amyloid properties $[15,16,18,19]$. Under polarized light microscopy, ordinary light microscopy and fluorescence microscopy, Congo red staining exhibits apple green double refraction, brick red and bright red, respectively [19]. In addition to the abovementioned typical pattern, the amyloid deposits also have other distribution forms in the cast, such as lamination form, which can present as two or more layers, and sometimes in a tree-ring shape [6-10,12, 19-21], and homogeneous form, which is composed of clumped homogeneous deposits distributed in the whole cast $[6,12,17,19]$. Electron microscopy shows numerous randomly arranged unbranched fibrils with a diameter of $8-12 \mathrm{~nm}$ in the amyloid structures of the casts $[6,13,15-17,19,21]$. Immunofluorescence or immunohistochemical examination reveals that the light chain in the cast has monoclonal properties, that is, only $\lambda$ or $\mathrm{K}$ light chain is present $[6,13-16,18-$ 21]. The morphological characteristics of the casts in Case 1 of this paper are completely consistent with those of LCAC above. Furthermore, in LCAC nephropathy, the amyloid casts usually coexist with the ordinary light chain protein casts. Gibier et al. [19] reported 17 cases of LCAC nephropathy, of which 16 cases were caused by MM. Among these cases, the proportion of amyloid 

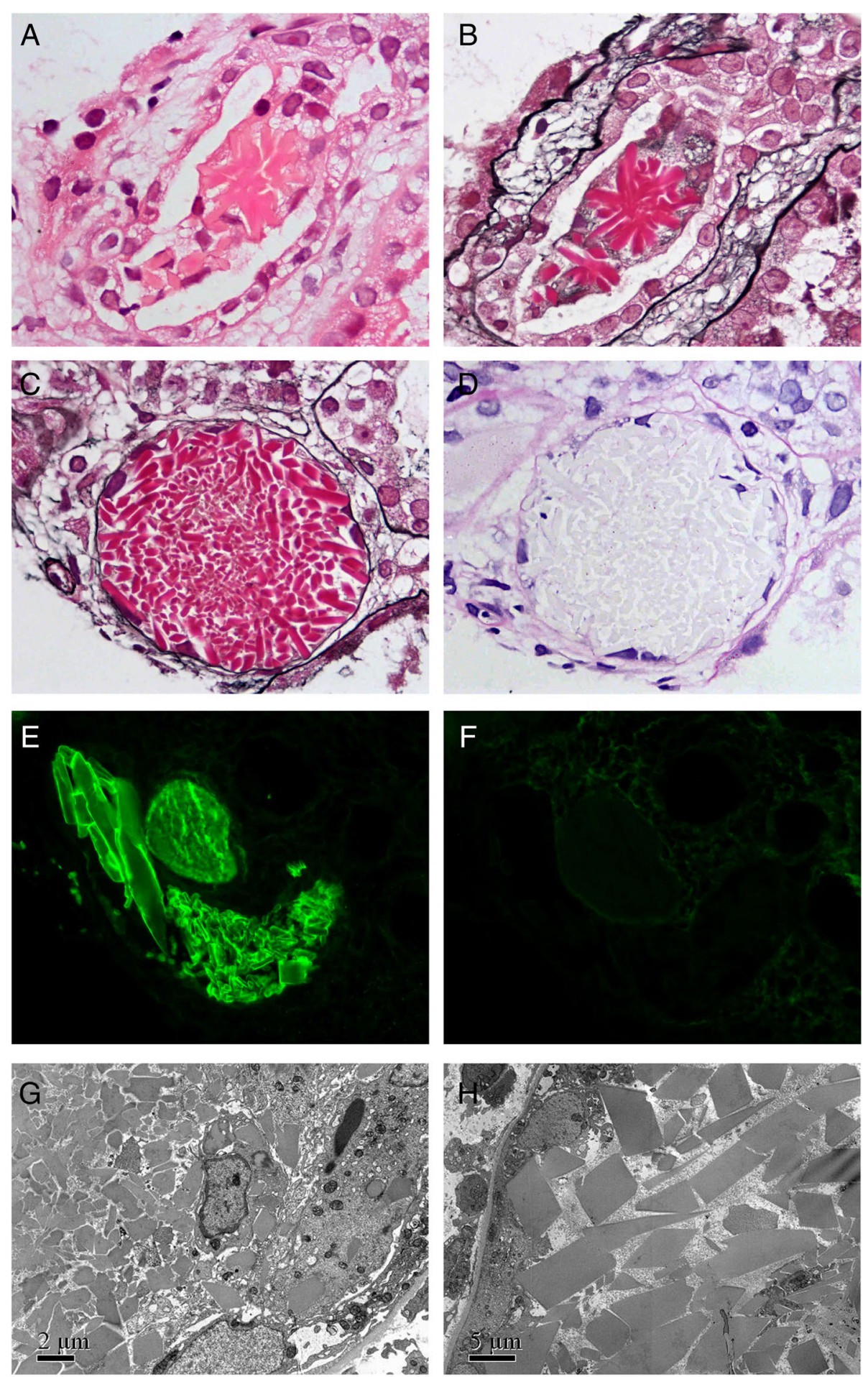

Fig. 3 Pathologic findings of kidney biopsy tissue in Case 2. A cast containing crystals of various geometric shapes, which was partially surrounded by mononuclear cells ( $\mathbf{a}$ and $\mathbf{b}$ ) (HE staining and PASM-Masson trichrome double staining respectively, both $\times 1000$ ). A cast consisting of a lot of crystals, around which the tubular epithelial cells have been destroyed or lost (c and $\mathbf{d}$ ) (PASM-Masson trichrome double staining and PAS staining respectively, both $\times 1000$ ). Casts with strong staining of $\lambda$ light chain $(\mathbf{e})$ and no staining of $\mathrm{k}$ light chain ( $\mathbf{f}$ ) (fluorescence micrographs $\times 400$ ). A lot of crystals with different sizes and shapes in a cast $(\mathbf{g}$ and $\mathbf{h}$ ) (electron micrographs $\times 8000$ and $\times 4000$, respectively) 
Table 1 Light chain amyloid in tubular casts and other tissues in multiple myeloma

\begin{tabular}{|c|c|c|c|c|c|c|c|}
\hline \multirow[t]{2}{*}{ References } & \multirow[t]{2}{*}{ Year } & \multirow{2}{*}{$\begin{array}{l}\text { No } \\
\text { of } \\
\text { cases }\end{array}$} & \multicolumn{3}{|l|}{ LCAC } & \multirow{2}{*}{$\begin{array}{l}\text { Other kidney tissue } \\
\text { amyloidosis }\end{array}$} & \multirow{2}{*}{$\begin{array}{l}\text { Extrarenal tissue } \\
\text { amyloidosis }\end{array}$} \\
\hline & & & Location & Pattern & Type & & \\
\hline Vassar PS [7] & 1962 & $33^{\mathrm{a}}$ & ND & $\begin{array}{l}\text { Rimmed } \\
\text { Laminated }\end{array}$ & ND & $\begin{array}{l}\text { PTC cytoplasm in } \\
\text { several cases }\end{array}$ & ND \\
\hline Azzopardi JG [8] & 1962 & $1^{a}$ & Distal & Laminated & ND & No & No \\
\hline Azzopardi JG [9] & 1966 & $1^{a}$ & ND & $\begin{array}{l}\text { Rimmed } \\
\text { Laminated }\end{array}$ & ND & No & $\begin{array}{l}\text { Yes in skin and } \\
\text { Pericardium, etc. }\end{array}$ \\
\hline Friman C [10] & 1970 & $1^{a}$ & Distal & Laminated & ND & No & $\begin{array}{l}\text { Yes in tumour, } \\
\text { No in other organs }\end{array}$ \\
\hline Limas C [11] & 1973 & $15^{\mathrm{a}}$ & $\begin{array}{l}\text { convoluted tubules, } \\
\text { loops of Henle, etc. }\end{array}$ & Rimmed & ND & $\begin{array}{l}\text { PTC cytoplasm in } \\
3 \text { cases }\end{array}$ & $\mathrm{No}^{\mathrm{c}}$ \\
\hline Melato M [12] & 1980 & $4^{a}$ & ND & $\begin{array}{l}\text { Rimmed } \\
\text { Laminated } \\
\text { Homogeneous }\end{array}$ & ND & No & No \\
\hline El-Zoghby Z [13] & 2007 & $1^{b}$ & ND & Rimmed & $\lambda$ & PTC cytoplasm & Yes in $\mathrm{BM}$ and joint \\
\hline Nasr SH [14] & 2008 & $1^{b}$ & ND & Rimmed & $\lambda$ & No & ND \\
\hline Sethi S [15] & 2009 & $1^{\mathrm{b}}$ & ND & Rimmed & $\lambda$ & No & No in BM \\
\hline Sharma A [16] & 2014 & $1^{b}$ & ND & Rimmed & $\lambda$ & No & No in BM \\
\hline Kato H [6] & 2015 & $1^{\mathrm{b}}$ & Distal & $\begin{array}{l}\text { Rimmed } \\
\text { Laminated Homogeneous }\end{array}$ & $\lambda$ & No & ND \\
\hline Iliuta IA [17] & 2016 & $1^{b}$ & Many segments & Homogeneous & $\lambda$ & PTC cytoplasm & ND \\
\hline Kurien AA [18] & 2018 & $1^{\mathrm{b}}$ & ND & $\begin{array}{l}\text { Rimmed } \\
\text { Homogeneous }\end{array}$ & $\lambda$ & PTC cytoplasm & ND \\
\hline Gibier JB [19] & 2018 & $16^{\mathrm{b}}$ & ND & $\begin{array}{l}\text { Rimmed } \\
\text { Laminated Homogeneous }\end{array}$ & $\begin{array}{l}\lambda^{\Delta} \\
\text { in } 13 \text { cases }\end{array}$ & $\begin{array}{l}\text { PTC cytoplasm in } \\
4 \text { cases }\end{array}$ & Yes in 5 cases \\
\hline Rajagopal MD [20] & 2018 & $1^{\mathrm{b}}$ & Distal & Laminated & $\lambda$ & No & No in BM and salivary gland \\
\hline Ichimata S [21] & 2020 & $1^{a}$ & ND & Laminated & $\lambda$ & PTC cytoplasm & Yes in lungs and heart \\
\hline Our case & & $1^{\mathrm{b}}$ & Distal & Rimmed & k & No & No in $\mathrm{BM}$ and arterioles \\
\hline
\end{tabular}

BM bone marrow, LCAC light chain amyloid casts, MM multiple myeloma, ND not detailed, PTC proximal tubular cell

${ }^{a}$ Autopsy kidney tissues; ${ }^{b}$ Kidney biopsy tissues

${ }^{c}$ Amyloid deposition was also found in the extrarenal organs of 8 elderly patients with amyloid casts. However, their amyloid deposition was not different from that of the age-matched controls, so it may not be related to the amyloid casts

casts in the total casts was $<5 \%$ in 9 cases, $5-25 \%$ in 3 cases and $>25 \%$ in 5 cases. In Case 1 of this paper, the amyloid casts accounted for $65 \%$ of all the casts.

The mechanism of LCAC formation remains unclear. It is known that the free light chains with a low molecular weight (approximately $20-25 \mathrm{kDa}$ ) can pass through the glomerular filtration membrane, while the amyloid fibrils with larger size cannot. Therefore, it can be inferred that the LCACs are formed in the tubules $[15,17$, 18]. There are two hypotheses. One possible mechanism is that the light chain proteins filtered into Bowman's space or the renal tubular lumen are affected by some environmental factors (such as the $\mathrm{pH}$ value of the filtrate and high concentration urea) to change their conformation and become amyloid proteins with $\beta$-fibril structure, and then aggregate to form LCACs in the distal tubules $[6,15,17,19,20]$. Another explanation is that the filtered light chain proteins are endocytosed by proximal tubular epithelial cells, undergo a conformational change under the action of lysosomal enzymes and obtain the properties of amyloid; these altered proteins are then discharged from the cells into the lumen to form the LCAC in the distal tubules [11, 15, 18-20]. The later hypothesis is supported by the fact that LCACs often coexist with amyloid light chain-mediated proximal tubulopathy [11, 13, 17-19].

Many patients with LCAC nephropathy do not have amyloid deposits in the glomeruli, tubular epithelial cells, renal small arteries and renal interstitium $[6,8-10$, $12,14-16,20]$, nor amyloidosis of extrarenal organs [8, $11,12,15,16,20]$. Even in some autopsy cases, no amyloid lesions in the above sites can be found $[8,12]$. The same is true for the patient described in Case 1 of this paper, whose renal parenchyma and bone marrow were negative for Congo red staining. Therefore, a question is raised; is there a link between LCAC and systemic amyloidosis? In 2018, a retrospective large sample study published by Gibier et al. [19] brought the answer to this question to light. After careful and systematic examinations of the tissues of the extrarenal organs (including 
biopsy tissues and surgical specimens) of patients with LCAC nephropathy caused by MM, the authors did observe amyloid deposits in some extrarenal organs and found that the formation of intratubular LCACs occurred earlier than extrarenal organ amyloidosis. Thus, that study suggests that LCAC may be a precursor of systemic amyloidosis. Based on the findings by Gibier et al. [19], we believe that all patients with LCAC should be carefully examined for the existence of systemic amyloidosis, and if not, a long term follow-up should be performed.

In the literature, only Gibier et al. [19] implemented a controlled cohort study of small samples that compared the response to treatment between the LCCN patients with and without amyloid casts. After treatment with bortezomib and immunomodulatory drug (lenalidomide or thalidomide)-based regimens, the hematological response (at least partial response) and renal response (defined by estimated glomerular filtration rate $\geq 30 \mathrm{ml} /$ $\mathrm{min} / 1.73 \mathrm{~m}^{2}$ and/or independence from dialysis at 3 months) were achieved in 68 and $32 \%$ of patients, respectively. The hematological and renal responses were not significantly different between the two groups. In addition, there were 3 case reports that described the renal response of patients with LCAC nephropathy after treatment. None of these patients exhibited significant improvement of renal function [13, 18, 20]. In Case 1 of this paper, $M M$ achieved partial remission after 4 courses of chemotherapy, but renal function did not improve concomitantly. The poor renal response of this patient may be caused by two factors: the response to therapy of LCAC nephropathy itself is not good, and the AKI of this patient occurred on the basis of chronic kidney disease (benign hypertensive nephrosclerosis with chronic renal insufficiency). Taken together, the response to therapy of LCAC nephropathy need to be further observed by expanding the number of cases.

Regarding LCCC caused by MM, the earliest data we retrieved were two individual case reports published by Silk [25] and Neumann [26] in 1949, respectively. However, it is said that LCCC was first reported by Löhlein in 1921 and published in a journal of pathology written in German [25]. In the published English literature, we retrieved 12 cases of LCCC confirmed by autopsy from 1949 to 1989 (one of the patients underwent renal biopsy before death) [25-30] and 27 cases of LCCC diagnosed by renal biopsy from 1987 to 2020 [31-43] (Table 2). Moreover, in two other papers, the authors mentioned that they also observed LCCC, but they did not provide detailed descriptions $[44,45]$.

The crystals in LCCC vary in size and shape. These crystals can appear as needle-shaped, bar-shaped, spindle-shaped, diamond-shaped, triangle, rectangle, pentagon, hexagon and other geometric shapes [25-43].
Some LCCCs are also surrounded by cellular reactions $[25,26,28,31,32,37]$. LCCCs are usually formed in the distal tubules, but occasionally can also form in the proximal tubules $[26,37,39]$. The staining properties of the crystalline casts are the same as those of ordinary light chain protein casts, appearing eosinophilic by HE staining, polychromatic (mixed red and blue) or fuschinophilic by Masson trichrome staining, pale by PAS staining and lack argyrophilic by PASM staining [38, 39, $42,46,47]$. If toluidine blue is used to stain semi-thin sections, the crystals appear blue with the best recognition effect [31]. Electron microscopy is also important for identifying and further confirming the crystalline casts. In addition, it has been reported in 3 articles that different shapes of crystals or/and crystalline casts were observed in the urinary sediment of patients with LCCC nephropathy [33, 37, 40]. Luciano et al. [37] believe that urinary sediment microscopy should be performed in all patients with monoclonal light chain-related nephropathy caused by MM, and this approach may provide important clues for the discovery of LCCC nephropathy. The histopathological features of the patient described in Case 2 in this paper are consistent with the LCCC nephropathy described above, and crystals were also found in the urine of this patient.

The mechanism of LCCC formation in patients with MM is still not well understood. There are several hypotheses. First, some light chain proteins more easily form crystals due to their individual characteristics (such as isoelectric point, glycosylation and amino acid sequence). When they are filtered from the glomerulus to the tubular lumen and reach a higher concentration in the tubule fluid, crystals may form under the action of certain local factors (such as a decreased $\mathrm{pH}$ value and a slower flow rate of the tubule fluid) [31, 34, 35]. Second, after the filtered light chain proteins are reabsorbed by proximal tubular epithelial cells, if the amount of lysosomal enzymes in the cytoplasm is insufficient, the function of lysosomal enzymes is deficient, or some light chain proteins (such as the $\mathrm{k}$ light chain belonging to the VKI subclass) are resistant to lysosomal enzymes, these light chains will accumulate in the lysosomes, and undergo homogenous polymerization to form crystals [3, $31,44,48]$. Then, these crystals fall off of the apical surface of the damaged epithelial cells into the tubular lumen, forming LCCCs [45]. Third, LCCC formation may be related with crystalglobulinemia. In this case, monoclonal globulins, or occasionally monoclonal light chains in the systemic vasculature can spontaneously form microcrystals and result in multiple organ embolism $[41,47,49]$. If the microcrystals embolize the glomerular capillaries and cause their destruction, the crystals in the circulation enter Bowman's space and the tubular lumen and then form crystalline casts in the distal 
Table 2 Light chain crystals in tubular casts and other tissues in multiple myeloma

\begin{tabular}{|c|c|c|c|c|c|c|}
\hline \multirow[t]{2}{*}{ References } & \multirow[t]{2}{*}{ Year } & \multirow{2}{*}{$\begin{array}{l}\text { No of } \\
\text { cases }\end{array}$} & \multicolumn{2}{|l|}{ LCCC } & \multirow[t]{2}{*}{ Other kidney tissues involved } & \multirow[t]{2}{*}{ Extrarenal tissue involved } \\
\hline & & & Location & type & & \\
\hline Sikl H [25] & 1949 & $1^{\mathrm{a}}$ & Distal & ND & PTC cytoplasm & NPC in medulla of the kidney \\
\hline Neumann V [26] & 1949 & $1^{\mathrm{a}}$ & All segments & ND & $\begin{array}{l}\text { Bowman's capsule } \\
\text { Interstitial cells }\end{array}$ & Bone marrow, NPC in tumour area \\
\hline Schubert GE [27] & 1972 & $7^{\mathrm{a}}$ & Distal & ND & $\begin{array}{l}\text { PTC cytoplasm } \\
\text { Interstitium }\end{array}$ & Bone marrow \\
\hline Chejfec G [28] & 1983 & $1^{\text {ba }}$ & ND & $\lambda$ & No & Lung \\
\hline Dornan TL [29] & 1985 & $1^{\mathrm{a}}$ & ND & $\lambda$ & $\begin{array}{l}\text { Bowman's capsule } \\
\text { Blood vessel }\end{array}$ & Interstitial tissue of the heart \\
\hline Truong LD [30] & 1989 & $1^{\mathrm{a}}$ & Distal & k & $\begin{array}{l}\text { PTC cytoplasm } \\
\text { Glomerulus } \\
\text { NPC in interstitium }\end{array}$ & No \\
\hline Pirani CL [31] & 1987 & $14^{\mathrm{bc}}$ & Distal & $\mathrm{k}$ or $\lambda$ & PTC or DTC cytoplasm (5 cases) & ND \\
\hline Kanno Y [32] & 2001 & $1^{\mathrm{b}}$ & ND & $\lambda ?$ & Bowman's capsule & Bone marrow \\
\hline Dehmel B [33] & 2003 & $1^{\mathrm{b}}$ & ND & $\lambda$ & PTC cytoplasm & ND \\
\hline Chen KJ [34] & 2005 & $1^{\mathrm{b}}$ & ND & $\lambda$ & Glomerulus, Blood vessel, Interstitium & Bone marrow \\
\hline Toly-Ndour C [35] & 2011 & $1^{\mathrm{b}}$ & ND & $\lambda$ & $\begin{array}{l}\text { PTC cytoplasm } \\
\text { Bowman's capsule }\end{array}$ & Bone marrow \\
\hline Haider M [36] & 2014 & $1^{\mathrm{b}}$ & Distal & $\lambda$ & No & ND \\
\hline \multirow[t]{2}{*}{ Luciano RL [37] } & 2014 & $1^{\mathrm{b}}$ & ND & $\lambda$ & No & ND \\
\hline & & $1^{\mathrm{b}}$ & Distal and Proximal & k & PTC cytoplasm & ND \\
\hline Gallan AJ [38] & 2016 & $1^{\mathrm{b}}$ & ND & $\lambda$ & No & ND \\
\hline Kumakura S [39] & 2016 & $1^{\mathrm{b}}$ & Proximal & $\lambda$ & No & ND \\
\hline Lerner G [40] & 2020 & $1^{\mathrm{b}}$ & Distal & k & PTC cytoplasm & ND \\
\hline Chou A [41] & 2020 & $1^{\mathrm{b}}$ & Distal & k & Glomerulus, Interlobular arteries & ND \\
\hline Matsumura H [42] & 2020 & $1^{\mathrm{b}}$ & Distal & $\lambda$ & No & No in bone marrow \\
\hline Lin Z-S [43] & 2020 & $1^{\mathrm{b}}$ & Distal & $\lambda$ & No & ND \\
\hline Our case & & $1^{\mathrm{b}}$ & Distal & $\lambda$ & No & No in bone marrow \\
\hline
\end{tabular}

LCCC light chain crystal casts, ND not detailed, NPC neoplastic plasma cells, PTC proximal tubular cell, DTC distal tubular cell

${ }^{a}$ Autopsy kidney tissues. ${ }^{b}$ Kidney biopsy tissue

' In this paper, definite crystals were detected histologically in 14 cases and features suggestive of crystals in another 4 cases. The 4 suspected cases are not included in this table

tubules. In the literatures, LCCCs can appear in three states: LCCCs existing alone [36-39, 42, 43], LCCCs coexisting with light chain crystal deposits of the proximal tubular epithelial cells [25, 27, 31, 33, 40], and in a few cases, LCCCs coexisting with light chain crystal deposits of the renal small vessels, glomerular capillaries, Bowman's space and even extrarenal tissues [26, 29, 30, $32,34,35,41]$. These three states may provide some circumstantial evidence for the above three LCCC formation mechanisms. Case 2 in our paper should belong to the first state.

LCCN usually causes AKI clinically, and severe cases often require dialysis treatment. LCCC nephropathy is no exception. Is there any difference in the response to treatment between LCCC nephropathy and ordinary LCCN? To date, too few cases of LCCC nephropathy have been treated, so it is impossible to draw a conclusion. In the literature, Haider et al. [36] and Kumakura et al. [39] each reported one patient with LCCC nephropathy; both patients developed AKI, and one patient underwent hemodialysis. After treatment with bortezomib-dexamethasone regimen, the MM of the patients achieved complete remission or good partial remission, respectively, the elevated serum creatinine levels returned to normal and the hemodialysis was stopped. Chou et al. [41] reported another patient with LCCC nephropathy with AKI undergoing dialysis. After receiving plasma-pheresis and 11 courses of the combined therapy of bortezomib, dexamethasone and cyclophosphamide, her MM achieved complete remission, renal function returned to nearly normal and hemodialysis was no longer needed. The patient described in Case 2 in this paper also obtained the same effects as above after treatment. Therefore, we believe that patients with LCCC nephropathy should not cease treatment for MM, even if they have received dialysis. 
The prognosis of treated $\mathrm{MM}$ and secondary AKI in these patients may still be very good and may be similar to those of ordinary LCCN. Of course, this view needs to be verified by a large number of treatment cases in the future.

In summary, LCAC nephropathy and LCCC nephropathy caused by MM are two rare types of $\mathrm{LCCN}$, and both have their own unique morphological characteristics. LCAC nephropathy may or may not be accompany with systemic light chain amyloidosis. LCCC nephropathy can exist alone or can coexist with crystalline LCPT or crystalglobu-linemia. In the urine of some patients with LCCC nephropathy, crystals may also be detected. The mechanisms of LCAC and LCCC formation are unclear. Is the response to treatment of LCAC nephropathy without systemic light chain amyloidosis better than that of treating LCAC nephropathy with systemic light chain amyloidosis? Is the response to treatment of LCCC nephropathy similar to that of ordinary LCCN? Both questions require further studies.

\section{Supplementary Information}

The online version contains supplementary material available at https://doi. org/10.1186/s12882-021-02250-z.

\section{Additional file 1.}

\section{Abbreviations}

AKl: acute kidney injury; HE: hematoxylin-eosin; LCAC: light chain amyloid cast; LCCC: light chain crystal cast; LCCN: light chain cast nephropathy; LCPT: light chain proximal tubulopathy; MM: multiple myeloma; PAS: periodic acid-Schiff; PASM: periodic acid silver methenamine

\section{Acknowledgments}

The authors thank to Professor Su-Xia Wang and her colleagues in the Laboratory of Electron Microscopy, Pathological Centre, Peking University First Hospital for their help in electron microscopy.

\section{Authors' contributions}

LS made major contributions in pathological diagnosis, pathological data collection and manuscript drafting. HD performed pathological technical work. XX and GW conducted clinical work and clinical data collection. HC was responsible for clinical work guidance and research supervision. YC made important contributions in reviewing pathological diagnosis and revising manuscript. All authors have read and approved the manuscript.

\section{Funding}

None.

\section{Availability of data and materials}

The datasets used and/or analysed during the current study are available from the corresponding author on reasonable request.

\section{Ethics approval and consent to participate}

This study was approved by the Ethics Review Committee of Beijing Anzhen Hospital (Number is 2020026X). All of the participants provided written informed consent at study entry.

\section{Consent for publication}

Written consent for publication was obtained from both patients reported herein.

\section{Competing interests}

All the authors declare no competing interests.

Received: 11 September 2020 Accepted: 19 January 2021

Published online: 28 January 2021

\section{References}

1. Nasr SH, Valeri AM, Sethi S, Fidler ME, Cornell LD, Gertz MA, et al. Clinicopathologic correlations in multiple myeloma: a case series of 190 patients with kidney biopsies. Am J Kidney Dis. 2012;59(6):786-94.

2. Dimopoulos MA, Sonneveld P, Leung N, Merlini G, Ludwig H, Kastritis E, et al. International myeloma working group recommendations for the diagnosis and management of myeloma-related renal impairment. J Clin Oncol. 2016;34(13):1544-57.

3. Sathick IJ, Drosou ME, Leung N. Myeloma light chain cast nephropathy, a review. J Nephrol. 2019;32(2):189-98.

4. Heher EC, Rennke HG, Laubach JP, Richardson PG. Kidney disease and multiple myeloma. Clin J Am Soc Nephrol. 2013;8(11):2007-17.

5. Lusco MA, Fogo AB, Najafian B, Alpers CE. AJKD atlas of renal pathology: light chain cast nephropathy. Am J Kidney Dis. 2016;67(3):e17-8.

6. Kato H, Fujigaki Y, Asakawa S, Yamaguchi Y, Uozaki H, Komatsuda A, et al. Rapid deterioration of the renal function caused by the coexistence of intratubular amyloidosis and myeloma cast nephropathy. Intern Med. 2015; 54(23):3023-8

7. Vassar PS, Culling CF. Fluorescent amyloid staining of casts in myeloma nephrosis. Arch Pathol. 1962:73:59-63.

8. Azzopardi JG. Clinicopathologic conference. A case of plasma cell leukemia. Br Med J. 1962;1(5272):169-77.

9. Azzopardi JG, Lehner T. Systemic amyloidosis and malignant disease. J Clin Pathol. 1966;19(6):539-48.

10. Friman C, Törnroth T, Wegelius O. IgD myeloma associated with multiple extramedullary amyloid containing-tumours and amyloid casts in the renal tubules. Ann Clin Res. 1970:2(2):161-6.

11. Limas C, Wright JR, Matsuzaki M, Calkins E. Amyloidosis and multiple myeloma. A reevaluation using a control population. Am J Med. 1973;54(2): 166-73.

12. Melato M, Falconieri G, Pascali E, Pezzoli A. Amyloid casts within renal tubules: a singular finding in myelomatosis. Virchows Arch A Pathol Anat Histol. 1980:387(2):133-45.

13. El-Zoghby Z, Lager D, Gregoire J, Lewin M, Sethi S. Intra-tubular amyloidosis Kidney Int. 2007;72(10):1282-8.

14. Nasr SH, Alobeid BB, Otrakji JA, Markowitz GS. Myeloma cast nephropathy, direct renal infiltration by myeloma, and renal extramedullary hematopoiesis. Kidney Int. 2008;73(4):517-8.

15. Sethi S, Hanna MH, Fervenza FC. Unusual casts in a case of multiple myeloma. Am J Kidney Dis. 2009;54(5):970-4.

16. Sharma A, Bansal S, Jain R. Unique morphology of intratubular light chain casts in multiple myeloma: the amyloid cast nephropathy. Indian J Pathol Microbiol. 2014;57(4):629-31.

17. Iliuta IA, Garneau AP, Latulippe E, Isenring P. Amyloid cast tubulopathy: a unique form of immunoglobulin-induced renal disease. Blood Cancer J. 2016;6(9):e474.

18. Kurien AA, Fernando ME. Amyloid proximal Tubulopathy and amyloid casts: an unusual finding in multiple myeloma. Indian J Nephrol. 2018:28(2):160-3.

19. Gibier JB, Gnemmi V, Glowacki F, Boyle EM, Lopez B, MacNamara E, et al. Intratubular amyloid in light chain cast nephropathy is a risk factor for systemic light chain amyloidosis. Mod Pathol. 2018;31(3):452-62.

20. Rajagopal MD, Ganesh RN, Parameswaran S, Puthiyottil D. Unusual morphology of amyloid cast nephropathy in renal biopsy portending poor prognosis. BMJ Case Rep. 2018;11(1):e225899.

21. Ichimata S, Hata Y, Abe R, Yoshinaga T, Katoh N, Kametani F, et al. An autopsy case of amyloid tubulopathy exhibiting characteristic spheroid-type deposition. Virchows Arch. 2020:477(1):157-63.

22. Defronzo RA, Humphrey RL, Wright JR, Cooke CR. Acute renal failure in multiple myeloma. Medicine (Baltimore). 1975:54(3):209-23.

23. Hill GS, Morel-Maroger L, Méry JP, Brouet JC, Mignon F. Renal lesions in multiple myeloma: their relationship to associated protein abnormalities. Am J Kidney Dis. 1983;2(4):423-38.

24. Rota S, Mougenot B, Baudouin B, De Meyer-Brasseur M, Lemaitre V, Michel C, et al. Multiple myeloma and severe renal failure: a clinicopathologic study 
of outcome and prognosis in 34 patients. Medicine (Baltimore). 1987;66(2): 126-37.

25. Sikl H. A case of diffuse plasmocytosis with deposition of protein crystals in the kidneys. J Pathol Bacteriol. 1949;61(2):149-63.

26. Neumann V. Multiple plasma-cell myeloma with crystalline deposits in the tumour cells and in the kidneys. J Pathol Bacteriol. 1949;61(2):165-9.

27. Schubert GE, Veigel J, Lennert K. Structure and function of the kidney in multiple myeloma. Virchows Arch A Pathol Pathol Anat. 1972;355(2):135-57.

28. Chejfec G, Natarelli J, Gould VE. "myeloma lung"--a previously unreported complication of multiple myeloma. Hum Pathol. 1983;14(6):558-61.

29. Dornan TL, Blundell JW, Morgan AG, Burden RP, Reeves WG, Cotton RE. Widespread crystallisation of paraprotein in myelomatosis. Q J Med. 1985; 57(222):659-67.

30. Truong LD, Mawad J, Cagle P, Mattioli C. Cytoplasmic crystals in multiple myeloma-associated Fanconi's syndrome. A morphological study including immunoelectron microscopy. Arch Pathol Lab Med. 1989;113(7):781-5.

31. Pirani CL, Silva F, D'Agati V, Chander P, Striker LM. Renal lesions in plasma cell dyscrasias: ultrastructural observations. Am J Kidney Dis. 1987;10(3):20821.

32. Kanno Y, Okada H, Nemoto H, Sugahara S, Nakamoto H, Suzuki H. Crystal nephropathy: a variant form of myeloma kidney--a case report and review of the literature. Clin Nephrol. 2001;56(5):398-401.

33. Dehmel B, Schneider W, Kettritz R, Luft FC. Not so acute renal failure with crystals in the urine. Nephrol Dial Transplant. 2003;18(1):209-11.

34. Chen KJ, Jan YJ, Chen CH, Cheng CH, Wu MJ, Shu KH. Multiple myelomaassociated cast nephropathy with crystal structure: case report and review of the literature. Nephrology (Calton). 2005;10(6):594-6.

35. Toly-Ndour C, Peltier J, Piedagnel R, Coppo P, Sachon E, Ronco P, et al. Acute renal failure with lambda light chain-derived crystals in a patient with IgD myeloma. Nephrol Dial Transplant. 2011;26(9):3057-9.

36. Haider M, Salvatore SP, Kaplan J, Seshan SV. Acute kidney injury due to tubular intraluminal monoclonal light chain crystals mimicking acute pyelonephritis. Ren Fail. 2014;36(2):300-5.

37. Luciano RL, Castano E, Fogazzi GB, Perazella MA. Light chain crystalline kidney disease: diagnostic urine microscopy as the "liquid kidney biopsy". Clin Nephrol. 2014;82(6):387-91.

38. Gallan AJ, Khalighi MA. Lambda light chain crystalline cast nephropathy and proximal tubulopathy. Kidney Int Rep. 2016;1 (4):316-20.

39. Kumakura S, Nakaya I, Sakuma T, Sato H, Soma J. Crystalline cast nephropathy in a patient with lgD lambda myeloma. Clin Exp Nephrol. 2016;20(3):491-2.

40. Lerner G, Moradi S, Cohen-Bucay A, Chen H, Sanchorawala V, Gordon CE, et al. Coincidental crystalline light chain cast nephropathy, light chain proximal tubulopathy, and urine crystallopathy: a case report and review of the literature. Clin Nephrol. 2020;93(4):203-8.

41. Chou A, Long C, Vonthethoff L, Ho SJ, Pettit F, Badve SV. Crystalglobulinemia in multiple myeloma: a rare case report of survival and renal recovery. Can J Kidney Health Dis. 2020;7:2054358120922629.

42. Matsumura H, Furukawa Y, Nakagaki T, Furutani C, Osanai S, Noguchi K, et al. Multiple myeloma-associated Ig light chain crystalline cast nephropathy. Kidney Int Rep. 2020;5(9):1595-602.

43. Lin ZS, Zhang X, Ma YY, Wang SX, Zhou FD. Crystalline light chain cast nephropathy in multiple myeloma. Korean J Intern Med. 2020. [Online ahead of print].

44. Messiaen T, Deret S, Mougenot B, Bridoux F, Dequiedt P, Dion JJ, et al. Adult Fanconi syndrome secondary to light chain gammopathy. Clinicopathologic heterogeneity and unusual features in 11 patients. Medicine (Baltimore). 2000;79(3):135-54

45. Stokes MB, Valeri AM, Herlitz L, Khan AM, Siegel DS, Markowitz GS, et al. Light chain proximal tubulopathy: clinical and pathologic characteristics in the modern treatment era. J Am Soc Nephrol. 2016;27(5):1555-65.

46. Herlitz LC, D'Agati VD, Markowitz GS. Crystalline nephropathies. Arch Pathol Lab Med. 2012;136(7):713-20

47. Cossey LN, Dvanajscak Z, Larsen CP. A diagnostician's field guide to crystalline nephropathies. Semin Diagn Pathol. 2020;37(3):135-42.

48. Sanders PW. Mechanisms of light chain injury along the tubular nephron. J Am Soc Nephrol. 2012;23(11):1777-81.

49. Ball NJ, Wickert W, Marx LH, Thaell JF. Crystalglobulinemia syndrome. A manifestation of multiple myeloma. Cancer. 1993;71(4):1231-4.

\section{Publisher's Note}

Springer Nature remains neutral with regard to jurisdictional claims in published maps and institutional affiliations.

\section{Ready to submit your research? Choose BMC and benefit from:}

- fast, convenient online submission

- thorough peer review by experienced researchers in your field

- rapid publication on acceptance

- support for research data, including large and complex data types

- gold Open Access which fosters wider collaboration and increased citations

- maximum visibility for your research: over $100 \mathrm{M}$ website views per year

At $\mathrm{BMC}$, research is always in progress.

Learn more biomedcentral.com/submissions 